\title{
Kajian Alih Wahana Cerita "Kedai Kopi Odyssey" Karya Leopold A. Surya Indrawan menjadi Naskah Drama
}

\author{
The Transformation Study "Kedai Kopi Odyssey" Story \\ by Leopold A. Surya Indrawan into Drama Script
}

\author{
Een Nurhasanah \\ Universitas Singaperbangsa Karawang \\ Jalan H. S. Ronggowaluyo, Telukjambe, Karawang, Jawa Barat, Indonesia \\ Email: een.nurhasanah@staff.unsika.ac.id; Orchid: https://orcid.id/0000-0002-1088-890X
}

\begin{abstract}
ARTICLE HISTORY
Received 11 December 2021

Accepted 10 January 2022

Published 1 February 2022

\section{KEYWORDS}

transformation, intrinsic element, extrinsic elements, the sociology of literature, drama script.

\section{KATA KUNCI}

alih wahana, unsur intrinsik, unsur ekstrinsik, sosiologi sastra, naskah drama.

ABSTRACT

The research study on the transfer of the story "Kedai Kopi Odyssey" by Leopold A. Surya Indrawan in the short story collection "Particles of God" Kompas 2014 aims to examine the process of converting stories into drama scripts and also analyze the social values contained therein. The selection of stories is based on the content of stories that contain social conflict. It is related to the approach used by the researcher, namely the sociology of literature approach. In addition to the sociology of literature approach, the researcher examines the process of transferring the story of "Kedai Kopi Odyssey" into a drama script. The analysis process is based on the intrinsic and extrinsic elements of literary works, then on transferring stories into drama scripts. Based on the analysis results, social values such as the value of tolerance and changes in sentence and diction in translating stories into drama scripts.

\section{ABSTRAK}

Penelitian kajian alih wahana cerita "Kedai Kopi Odyssey" karya Leopold A. Surya Indrawan dalam kumpulan cerita pendek "Partikel-partikel Tuhan" Kompas 2014 bertujuan untuk mengkaji proses pengalihwanaan cerita ke dalam naskah drama dan juga menganalisis nilai-nilai sosial yang terkandung di dalamnya. Pemilihan cerpen berdasarkan isi cerita yang bermuatan konflik sosial. Hal ini berkaitan dengan pendekatan yang digunakan peneliti yaitu pendekatan sosiologi sastra. Selain pendekatan sosiologi sastra, peneliti mengkaji proses alih wahana cerita "Kedai Kopi Odyssey" ke dalam naskah drama. Proses analisis berdasarkan unsur intrinsik dan ekstrinsik karya sastra, kemudian analisis proses alih wahana cerita ke dalam naskah drama. Berdasarkan hasil analisis ditemukan nilai-nilai sosial seperti nilai toleransi serta perubahan-perubahan kalimat maupun diksi dalam proses pengalihwahaan cerita ke dalam naskah drama.
\end{abstract}

To cite this article:

Nurhasanah, E. (2022). Kajian Alih Wahana Cerita "Kedai Kopi Odyssey" Karya Leopold A. Surya Indrawan menjadi Naskah Drama. Diglosia: Jurnal Kajian Bahasa, Sastra, dan Pengajarannya, 5(1), 175-194. https://doi.org/10.30872/diglosia.v5i1.355 


\section{A. Pendahuluan}

Karya sastra merupakan sebuah karya yang dapat memberikan nilai-nilai kehidupan serta dapat menghibur para penikmatnya. Sastra itu sendiri memiliki hubungan yang erat dengan kehidupan masyarakat. Hal ini dapat dikuatkan dengan banyaknya hasil dari karya sastra yang mengangkat kisah dalam kehidupan dan kenyataan sosial masyarakat. Salah satu bagian dari karya sastra ialah prosa fiksi, karya sastra lebih banyak mengangkat kisah dalam kehidupan seseorang, sosial dan agama. Dapat diketahui bahwa prosa fiksi merupakan sebuah karya sastra yang isinya mengenai rangkaian peristiwa para tokoh secara keseluruhan, selain itu isi dari cerita dalam prosa fiksi biasanya merupakan rekaan atau khayalan dari pengarangnya semata, tidak sepenuhnya berdasarkan dalam kehidupan nyata.

Salah satu bentuk dari prosa fiksi ialah cerpen, cerpen merupakan sebuah cerita pendek yang hanya berfokus pada satu peristiwa saja, cerita yang ditulis pengarang pun biasanya tidak benar-benar terjadi atau hanya rekaan. Hal ini sependapat dengan Nurgiyantoro (2013) bahwa cerpen adalah fiksi pendek yang selesai dibaca dalam sekali duduk. Cerita pendek hanya memiliki satu arti, satu krisis dan satu efek untuk pembacanya. Isi dalam cerpen banyak menitikberatkan pada kehidupan masyarakat, sosial dan agama. Seperti yang terdapat dalam cerita "Kedai Kopi Odyssey" dalam kumpulan cerpen Partikel-Partikel Tuhan Karya Leopold Adi Surya Indrawan (2014). Menyikapi hal tersebut maka perlu adanya sebuah pendekatan kemasyarakatan dan melibatkan berbagai disiplin ilmu untuk menggali lebih dalam terkait unsur intrinsik dan ekstrinsik yang terdapat dalam cerita tersebut. Pendekatan yang dapat digunakan salah satunya adalah pendekatan sosiologi sastra. Pendekatan sosiologi sastra merupakan sebuah pendekatan yang mengungkapkan bahwa karya sastra erat hubungannya dengan kehidupan masyarakat. Wolff berpendapat bahwa sosiologi sastra merupakan disiplin yang tanpa bentuk, tidak terdefinisikan dengan baik, terdiri dari sejumlah studi-studi empiris dan berbagai percobaan teori yang agak lebih general yang masing-masing hanya mempunyai kesamaan dalam hal berurusan dengan hubungan sastra dan masyarakat (Endraswara, 2013). Sejalan dengan itu, Endraswara (2013, hal. 78) menyatakan bahwa sosiologi objek studinya tentang manusia dan sastra pun demikian. Sastra adalah ekspresi kehidupan manusia yang tak lepas dari akar masyarakatnya. Dari dua pendapat ahli tersebut dapat kita ketahui bahwa pendekatan sosiologi sastra sangat relevan digunakan untuk karya sastra yang isi ceritanya banyak mengangkat kehidupan masyarakat.

Selain itu, penulis mencoba mengalihwahanakan cerita "Kedai Kopi Odyssey" karya Leopold Adi Surya Indrawan ke dalam bentuk naskah drama. Alih wahana merupakan kajian transformasi karya sastra dari satu bentuk ke bentuk lain. Sejalan dengan itu, Damono (2012) berpendapat bahwa alih wahana adalah perubahan dari satu jenis kesenian ke jenis kesenian lain. Kajian alih wahana sudah banyak dilakukan. Perubahan bentuk karya sastra tersebut ada yang mengarah pada puisi, cerpen, drama, film, musik, seni tari, seni rupa, dan lain sebagainya. 
Ada beberapa penelitian relevan dengan penelitian ini. Penelitian pertama adalah artikel yang ditulis oleh Nurhasanah (2019), memfokuskan pembahasan alih wahana atau ekranisasi yang semula berbentuk cerpen diolah menjadi naskah drama. Dalam penelitiannya, perubahan cerpen ke dalam naskah drama terdapat pada unsur dialog, tokoh, dan latar tempat. Berdasarkan cerpen yang digunakan, hasil analisisnya juga mengarah pada analisis psikologi sastra pada tokoh. Tokoh yang dirujuk adalah tokoh utama. Untuk mengetahui psikologi tokoh utama tersebut, peneliti menggunakan pendekatan psikologi sastra. Kemudian penelitian yang ditulis Rahma \& Meinati (2021) memfokuskan kajiannya pada cerpen yang diadaptasi ke dalam film. Perubahan yang terjadi meliputi perubahan variasi, penambahan, dan penciutan pada unsur alur, tokoh, dan latar. Pendekatan yang digunakan dalam ekranisasi tersebut menggunakan pendekatan loose (lepas). Penelitian dengan fokus serupa juga ditulis oleh Jafar Fakhrurozi \& Adrian (2021) memfokuskan kajian alih wahana cerpen ke film Perubahan yang terjadi dalam proses alih wahana tersebut di antaranya pengurangan jumlah episode yang semula 29 episode hanya menjadi 26 episode saja. Selain itu terdapat pula pengurangan tokoh serta dilakukan serta perubahan variasi lainnya terkait judul, tokoh, latar, dan episode. Dalam penelitian ini tidak memfokuskan pada kajian analisis dengan pendekatan sastra, melainkan pada proses alih wahana terhadap pembelajaran sastra membuat film ekranisasi.

Berdasarkan penelitian-penelitian yang telah dipaparkan di atas, dapat diketahui bahwa sudah banyak sekali kajian alih wahana, khususnya yang bermula dari bentuk cerpen. Meskipun demikian, dapat ditarik benang merah bahwa terdapat perbedaan yang signifikan antara penelitian tersebut dengan kajian yang dibahas dalam makalah ini.

Selanjutnya, penelitian yang membahas naskah drama, ditemukan pada penelitian yang dilakukan oleh Lesmana, Udasmoro, \& Hayuningsih (2021) yang membahas tentang habitus. Habitus membentuk interaksi yang konstan dan berulang di antara subjek. Hal ini dipengaruhi oleh posisi subyek berdasarkan modal sosial yang dimilikinya. Perbedaan kelas sosial pada naskah drama Les Bonnes karya Jean Genet menyebabkan adanya kelas pekerja dan kelas dominan.

Hasil pembahasan makalah ini berfokus pada cerita "Kedai Kopi Odyssey" ke dalam naskah drama "Kedai Kopi Odyssey" dengan merujuk pada pendekatan sosiologi sastra. Cerpen "Partikel-partikel Tuhan" ini hanya terdiri dari 11 halaman yang terbagi menjadi 4 cerita yang berbeda, yaitu (1) "Odin", (2) "di Bawah Pohon Sesawi", (3) "Kedai Kopi Odyssey", dan (4) "Planet Knosso". Teknik penulisan cerpen sangat unik, karena ada beberapa cerita di dalam satu cerpen. Keempat cerita yang berada dalam satu cerpen tersebut secara alur cerita maupun penokohan dan latar tidak saling berkaitan. Alur antar cerita dalam satu cerpen memiliki alur cerita masing-masing. Inilah keunikan gaya kepenulisan Karya Leopold Adi Surya Indrawan yang menjadi pertimbangan dalam pemilihan cerpen yang dialihwahanakan. Peneliti memilih satu cerita berjudul "Kedai Kopi Odyssey" yang berada dalam cerpen "Partikel-partikel Tuhan" ke dalam naskah drama. 
Dalam cerita "Kedai Kopi Odyssey", penulis ingin mengungkapkan berbagai masalah yang dialami manusia terkait konsepsi Tuhan dari sudut pandang yang berbeda. Bentuk penceritaannya pun ada yang benar-benar nyata dengan kehidupan manusia dan ada pula yang imaji. Berdasarkan hasil pembacaan cerita "di Bawah Pohon Sesawi" dan "Kedai Kopi Odyssey" lebih dekat dengan refleksi dan kenyataan kehidupan sosial manusia dalam masyarakat, sedangkan "Odin" dan "Planet Knossos" terdapat unsur imaji yang tidak mungkin terjadi pada manusia di kehidupan masyarakat. Karena kajian ini berfokus pada cerita "Kedai Kopi Odyssey", maka pendekatan yang tepat digunakan adalah sosiologi sastra dengan menekankan pada aspek realitas sosial.

Menurut Ratna (2013)sosiologi sastra hakikatnya adalah interdisipliner antara sosiologi dengan sastra, keduanya memiliki objek yang sama, yaitu manusia dalam masyarakat. Konsep sosiologi sastra didasarkan pada dalil bahwa karya sastra diciptakan oleh seorang pengarang di mana pengarang itu sendiri merupakan a salien being, yakni makhluk yang mengalami dan menjadi bagian dalam kehidupan empiris sosial kemasyarakatan (Mahsa, 2021; Sehandi, 2014).

Wellek \& Warren membagi telaah sosiologis menjadi tiga klasifikasi (Tyas, 2018). Pertama, sosiologi pengarang. Sosiologi pengarang mempermasalahkan tentang status, ideologi politik, dan lai-lain yang menyangkut diri pengarang. Kedua, sosiologi karya sastra. Sosiologi karya sastra mempermasalahkan tentang suatu karya sastra: yang menjadi pokok adalah tentang apa yang tersirat dalam karya sastra tersebut dan apa tujuan atau amanat yang hendak disampaikannya. Ketiga, sosiologi pembaca. Sosiologi pembaca mempermasalahkan tentang pembaca dan pengaruh sosialnya terhadap masyarakat. Kemudian fungsi sosial sastra, meliputi (1) sejauh mana sastra dapat berfungsi sebagai perombak masyarakatnya; (2) sejauh mana sastra hanya berfungsi sebagai penghibur saja; dan (3) sejauh mana terjadi sintesis antara dua kemungkinan tersebut (Rosdiani, Nurhasanah, \& Triyadi, 2021).

Sebagaimana telah disinggung di atas, kenyataan yang terjadi pada manusia di kehidupan sosial masyarakatnya merupakan realitas sosial. Hal ini sejalan dengan pendapat bahwa realitas sosial dapat disebut juga dengan gambaran kehidupan masyarakat yang benar-benar terjadi dan berkaitan dengan kegiatan manusia yang disuguhkan secara nyata dalam kehidupan (Rosdiani et al., 2021). Selain itu, menurut Ritzer (2014), mengungkapkan bahwa realitas sosial adalah cara bertindak tetap atau tidak yang bisa menjadi pengaruh atau suatu hambatan eksternal bagi seorang individu. Dengan demikian dapat disimpulkan bahwa realitas sosial adalah kenyataan yang terjadi pada manusia di tengah kehidupan sosial masyarakat dan hasil dari interpretasi manusia itu sendiri.

Ritzer (2014) membagi realitas sosial menjadi dua tipe, yakni realitas sosial objektif dan realitas sosial subjektif. Realitas sosial objektif merupakan suatu gejala sosial yang terjadi dalam kehidupan sehari-hari dan sering dihadapi semua masyarakat. Hal tersebut membuktikan bahwa kehidupan manusia hanyalah suatu objek dan sasaran dari suatu aturan (Rosdiani et al., 2021, hal. 87). Menurut Hidayaturrahman (2020) manusia merupakan instrumen di dalam penciptaan realitas sosial yang objektif melalui proses eksternalisasi, 
sebagaimana ia mempengaruhinya melalui proses internalisasi. Sedangkan realitas sosial subjektif merupakan suatu pemahaman realitas sosial yang terbentuk dari diri khalayak individu yang berasal dari realitas sosial objektif. Dapat dikatakan bahwa kehidupan sosial manusia dalam sehari-harinya dapat dilihat dari sisi subjeknya ataupun sudut pandang pelakunya, agar memiliki kejelasan sudut pandang yang lebih luas.

Setelah mengkaji realitas sosial dan memahami secara struktural, cerita "Kedai Kopi Odyssey" dalam kumpulan cerpen "Partikel-partikel Tuhan", kemudian diubah ke dalam bentuk naskah drama melalui proses alih wahana. Istilah alih wahana yang secara singkat dapat dijelaskan sebagai perubahan suatu bentuk karya seni ke bentuk karya seni lain. Perubahan yang dimaksud dalam teori tersebut adalah adaptasi wahana atau media penyampaiannya (Damono, 2012).

Menurut Nurhasanah (2019), kajian alih wahana merupakan salah satu alternatif karya sastra agar lebih menarik dan mengalami perubahan sesuai perkembangan zaman serta bisa kolaborasi dengan bidang lain. Pemanfaatan teori ataupun kajian alih wahana untuk memperkenalkan sastra ke bidang yang lain. Ada empat bentuk alih wahana, yaitu (1) ekranisasi; (2) musikalisasi; (3) dramatisasi; dan (4) novelisasi. Berdasarkan paparan tersebut, bentuk alih wahana yang akan dilakukan terhadap cerita "Kedai Kopi Odyssey" dalam cerpen "Partikel-partikel Tuhan" ini adalah dramatisasi, yakni mengubah ke bentuk naskah drama. Adapun tujuan dari penelitian ini, yaitu: (1) untuk memahami unsur intrinsik dalam cerita "Kedai Kopi Odyssey" karya Leopold Adi Surya Indrawan; (2) mengkaji unsur ekstrinsik dalam cerita "Kedai Kopi Odyssey" karya Leopold Adi Surya Indrawan yang mengandung nilai-nilai sosial; dan (3) untuk mengetahui proses alih wahana dalam cerita "Kedai Kopi Odyssey" karya Leopold Adi Surya Indrawan.

\section{B. Metode}

Ratna (2013, hal. 47) menyatakan bahwa pendekatan kualitatif berkaitan dengan fakta ilmiah, yaitu tentang konteks keberadaan mereka. Pendekatan ilmiah yang mempromosikan metode kualitatif disebut multi-metode, karena penelitian memerlukan berbagai fenomena sosial yang signifikan. Dalam analisis sastra, misalnya, penulis, lingkungan sosial di mana penulis tinggal, dan komponen budaya, secara umum, akan dipertimbangkan. Fenomena yang terdapat pada cerita "Kedai Kopi Odyssey" karya Leopold A. Surya Indrawan merupakan cerminan kehidupan sosial masyarakat yang suka mengobrol di kedai kopi. Maka metode yang digunakan dalam menganalisis adalah metode kulitatif.

Menurut Sugiyono (2016), objek penelitian adalah atribut, sifat, atau nilai orang, benda, atau kegiatan yang diteliti dan kesimpulan tercapai. Berdasarkan kesimpulan ini, objek penelitian adalah hasil yang diinginkan, yaitu mengubah cerita pendek menjadi naskah drama. Dalam penelitian kualitatif, peneliti adalah instrumen atau alat. Sebagai instrumen manusia, peneliti mengumpulkan data, 
menganalisis, menafsirkan, dan mengubah cerita pendek menjadi naskah drama serta menyimpulkan hasil analisis.

Metode penelitian yang dipilih dalam penelitian ini adalah deskriptif yaitu metode yang menguraikan data-data dalam bentuk kata-kata, bukan dalam bentuk angka. Metode deskriptif adalah sifat data penelitian kualitatif yang wujud datanya berupa deskripsi objek penelitian (Moleong, 2016). Dengan kata lain, wujud data penelitian kualitatif adalah kata-kata, gambar, angka-angka yang tidak dihasilkan melalui pengolahan statistika. Data yang banyak itu disusun, diulas satu-satu, dianalisis secara rinci sehingga diperoleh laporan komprehensif. Wujud data metode deskriptif dari penelitian ini yaitu cerita pendek "Kedai Kopi Odyssey" karya Leopold A. Surya Indrawan dalam kumpulan cerpen koran Tempo Minggu 2014. Kumpulan cerpen yang berupa buku elektronik tidak dijualbelikan secara umum dan bisa diunduh secara gratis di internet. Kumpulan cerpen berjudul "Partikel-partikel Tuhan" yang diambil dari judul salah satu cerpen yang terdapat dalam kumpulan cerpen tersebut. Jumlah keseluruhan halaman buku kumpulan cerpen berjumlah 431 halaman, sedangkan cerpen "Partikel-partikel Tuhan" karya Leopold A. Surya Indrawan berada pada halaman 9 sampai dengan 19 yang terdiri empat cerita pendek di dalamnya, salah satunya cerita "Kedai Kopi Odyssey" yang menjadi objek alih wahana peneliti menjadi naskah drama.

Penelitian ini bertujuan untuk memeriksa dan mengubah narasi pendek menjadi naskah untuk sebuah drama. Data kualitatif dijelaskan dan diperiksa dengan cermat dalam penyelidikan ini. Deskripsi ini memerlukan mendokumentasikan, mempelajari, menyusun, dan mengklasifikasikan cerita pendek "Kedai Kopi Odyssey" karya Leopold A. Surya Indrawan dalam hal struktur yang melekat dan proses mengubah cerita pendek menjadi naskah drama.

Penelitian ini menggunakan teknik parafrase. Pendekatan parafrasetik adalah strategi untuk memahami makna yang terkandung dalam karya sastra dengan mengekspresikan kembali ide-ide penulis menggunakan kata-kata atau kalimat yang berbeda dari penulis sendiri, berniat untuk menyederhanakan penggunaan kata-kata atau kalimat penulis sehingga pembaca dapat lebih mudah memahami isi makna yang terkandung dalam karya sastra (Aminuddin, 2015, hal. 41).

Langkah-langkah penelitian ini adalah sebagai berikut: (1) membaca keseluruhan cerita "Kedai Kopi Odyssey" karya Leopold A. Surya Indrawan dengan cermat serta menandai penggalan-penggalan cerpen; (2) menganalisis dan menginterpretasi data yang sesuai dengan kata kunci berdasarkan landasan teoretis; (3) menganalisis proses alih wahana cerita yang diubah menjadi naskah drama; dan (4) menyimpulkan hasil analisis alih wahana cerita ke dalam naskah drama. Proses selanjutnya mengalihwahanakan cerita menjadi naskah drama, (1) membaca keseluruhan cerita secara lengkap dan menandai bagian-bagian yang akan dijadikan naskah drama; (2) menyusun alur cerita sesuai dengan isi cerita; (3) menentukan alur dan karakter sesuai dengan isi cerita; (4) menyusun konflik hingga klimaks yang menjadi alur dalam naskah drama sesuai dengan alur cerita. 


\section{Pembahasan}

\section{Analisis Unsur Intrinsik}

Unsur intrinsik adalah unsur-unsur yang membangun karya sastra itu sendiri atau dapat dikatakan juga sebagai unsur pembangun dari dalam karya sastra. Unsur-unsur inilah yang menyebabkan suatu teks hadir sebagai teks sastra, unsur-unsur yang secara faktual akan dijumpai jika orang membaca karya sastra (Nurgiyantoro, 2013). Berikut ini adalah unsur-unsur dari dalam yang membangun cerita "Kedai Kopi Odyssey" karya Leopold A. Surya Indrawan yang ditulis dalam cerpen "Partikel-partikel Tuhan" sebagai berikut.

\section{a. Alur}

Alur adalah sebuah susunan atau jalanya sebuah cerita yang saling berhubungan antara peristiwa satu dengan yang lain. Setiap cerita pasti memiliki jalan cerita yang berbeda. Ada tiga ragam alur yaitu alur maju (progresif), alur mundur (sorot balik), dan alur campuran. Alur yang baik adalah alur yang bisa membantu mengungkapkan tema dan amanat sehingga timbul hubungan sebabakibat. Cerita "Kedai Kopi Odyssey" menggunakan alur maju (progresif). Pengarang menyampaikan ceritanya dengan urut mulai dari tahap eksposisi, tahap komplikasi, tahap klimaks, sampai tahap resolusi. Pada alur maju tidak ada kilas balik yang diceritakan. Tokoh dalam cerita "Kedai Kopi Odyssey" tidak menceritakan pengalaman masa lalu yang pernah dialami tokoh tersebut. Bisa dilihat dengan jelas bahwa alur yang digunakan maju, dengan memperhatikan tahap-tahap alur sebagai berikut.

\section{(1) Tahap Eksposisi}

Pada bagian ini pengarang mulai memperkenalkan cerita yang diawali dengan penggambaran suasana kedai dengan cuaca yang sedang mendung, dan diisi dengan potongan musik. Di kedai yang ada di kota J, terdapat sepang kekasih yang sedang berbincang-bincang membicarakan suatu hal yang tidak ada ujungnya. Dapat dilihat dari kutipan berikut.

Suasana kelam dipekatkan oleh cuaca yang mendung. Hanya sedikit lampu yang menerangi kedai itu. Tiap mejanya disekat dengan balok kaca hitam yang menjulang.

Di meja nomor 11 yang bersisian dengan jendela yang menghadap ke kota $\mathrm{J}$, sepasang kekasih, lelaki dan perempuan, sedang seru membicarakan sesuatu.

Dari kutipan tersebut membuktikan bahwa suasana kelam menyelimuti kedai itu, karena dipekatkan oleh cuaca yang mendung. Ada sepasang kekasih yang sedang asyik membicarakan suatu hal. 


\section{(2) Tahap Komplikasi}

Pada tahap ini pengarang memperkenalkan peristiwa yang disajikan yaitu peristiwa awal yang menimbulkan berbagai masalah, pertentangan ataupun kesukaran-kesukaran bagi para tokohnya. Awal permasalahan muncul ketika Rick mempercayai bahwa semua yang terjadi di dunia ini hanyalah rangkaian kebetulan saja, tidak ada campur tangan dari Tuhan. Perhatikan kutipan berikut ini.

\footnotetext{
"Kebetulan, Rachel! Itu semua terjadi karena rangkaian kebetulan!" "Kau percaya dengan kebetulan?"

"Tentu! Aku tak mau... apalagi jika untuk membenarkan segala perkara yang terjadi di dunia ini... percaya bahwa ada makhluk yang begitu peduli dengan kita, ingin mengatur segala sesuatu tentang kita. Apa pentingnya buat Dia? Jika hanya untuk disembah dan dipatuhi, betapa la begitu obsesif dan... hmmm... rapuh."
}

Kutipan tersebut membuktikan bahwa kemunculan konflik yang berawal dari kepercayaan Rick terhadap sesuatu yang terjadi hanya sebuah kebetulan belaka. Karena menurut Rick tidak ada yang peduli dengan kehidupan mereka dan tidaklah penting mengatur hidup mereka.

\section{(3) Tahap Klimaks}

Peristiwa selanjutnya ini adalah puncak konflik atau klimaks, di mana inti cerita semakin mencengkam dan menegangkan. Puncak konflik dalam cerita ini adalah ketika Rachael bertanya apakah salah jika ada Tuhan yang memiliki kepentingan. Dari situ terjadi perdebatan antara Rachael dan Rick yang membicarakan konsepsi Tuhan. Dapat dilihat pada kutipan berikut.

"Lantas, jika memang Tuhan...atau apa pun itu yang bisa disebut sebagai entitas superior...memiliki kepentingan, apakah itu salah?"

"Barangkali tidak. Tetapi, Tuhan yang memiliki kepentingan adalah Tuhan yang 'dimanusiakan'... dan itu sungguh banal, seperti khayalan orang-orang zaman dulu. Tuhan diibaratkan seorang bapak tua berjanggut, mengapung-apung di langit, seenaknya mengatur hidup-mati seseorang, doyan memerintah, senang disembah dan dipuji. Seperti Tuhan dalam Pentateuch, misalnya. la begitu pemarah, bertingkah layaknya seorang tiran. Apakah kau sudi percaya pada Tuhan yang seperti itu?"

Dari kutipan di atas dapat dibuktikan bahwa menurut Rick jika ada Tuhan yang memiliki kepentingan hanyalah Tuhan yang 'dimanusiakan'. Tuhan yang hanya mengatur hidup seseorang, suka memerintah, suka disembah dan dipuji.

\section{(4) Tahap Resolusi}

Kemudian pada tahap ini konflik yang telah mencapai klimaks diberi jalan keluar, cerita diakhiri, atau akhir dari cerita. Penyelesaian dalam cerita ini ketika Rick dan Rachael menyadari bahwa pembicaraan mereka tidak akan ada ujungnya, pada akhirnya mengalihkan pembicaraan. Dan di akhir cerita mereka 
berdua dikejutkan oleh suara bom. Dibuktikan dari kutipan berikut.

"Kita seharusnya membicarakan rencana kursus pernikahan kita, Sayaaaang! Bukan ngomongin sesuatu yang enggak pernah ada ujungnya ini!"

Rachael dan Rick menatap beku ke tempat yang sama. Di antara permukiman penduduk yang menghampar di bawah sana, hanya beberapa kilometer dari tempat mereka berada saat ini, Gereja Santo Fransiskus baru saja diruntuhkan oleh bom.

Dari kutipan tersebut dapat dilihat bahwa seharusnya membicarakan pernikahan mereka, bukan tentang konsepsi Tuhan yang tidak akan ada ujungnya. Dan yang paling mengejutkan tiba-tiba terdengar suara ledakan bom yang meruntuhkan Gereja Santo Fransiskus.

\section{b. Tokoh dan Penokohan}

Terdapat dua tokoh dalam cerita yang digambarkan oleh pengarang. Berikut uraian mengenai tokoh berserta penokohannya.

\section{(1) Rick}

Dalam cerita "Kedai Kopi Odyssey" yang ditulis dalam cerpen "Partikelpartikel Tuhan" Rick digambarkan sebagai seorang yang memiliki kepribadian yang pemberani, dia berani mengeluarkan pendapat atau argumen yang hendak ia sampaikan. Kemudian yang selanjutnya keras kepala, ketika Rick berargumen, jika menurut dia itu benar maka dia akan tetap mempertahankan argumennya. Di satu sisi Rick juga memiliki kepribadian yang terbuka, dia tetap menghargai pendapat apa pun yang dilontarkan oleh lawan bicaranya. Dapat dilihat pada kutipan berikut.

"Tentu! Aku tak mau... apalagi jika untuk membenarkan segala perkara yang terjadi di dunia ini... percaya bahwa ada makhluk yang begitu peduli dengan kita, ingin mengatur segala sesuatu tentang kita. Apa pentingnya buat Dia? Jika hanya untuk disembah dan dipatuhi, betapa la begitu obsesif dan... hmmm... rapuh."

"Barangkali tidak. Tetapi, Tuhan yang memiliki kepentingan adalah Tuhan yang 'dimanusiakan'... dan itu sungguh banal, seperti khayalan orang-orang zaman dulu. Tuhan diibaratkan seorang bapak tua berjanggut, mengapung-apung di langit, seenaknya mengatur hidup-mati seseorang, doyan memerintah, senang disembah dan dipuji. Seperti Tuhan dalam Pentateuch, misalnya. la begitu pemarah, bertingkah layaknya seorang tiran. Apakah kau sudi percaya pada Tuhan yang seperti itu?"

Kutipan tersebut dengan jelas membuktikan bahwa Rick memiliki kepribadian yang pemberani, dia berani mengeluarkan pendapat mengenai konsepsi Tuhan dari sudut pandang Rick.

"Kebetulan, Rachel! Itu semua terjadi karena rangkaian kebetulan!" "Kau percaya dengan kebetulan?"

"Tentu! Aku tak mau... apalagi jika untuk membenarkan segala perkara yang terjadi di dunia ini..." 
Pada kutipan di atas dapat dilihat karakter keras kepala yang dimiliki oleh Rick. Rick tetap mempercayai bahwa semua yang terjadi di dunia ini hanya sebuah kebetulan belaka.

"Sifat-sifat itu, menurutku ya, hanya representasi dari apa yang tak mungkin ditafsirkan oleh indra manusia, Rick. Seperti seorang penulis memberi watak pada tokoh ceritanya."

"Dan itulah yang membuat orang-orang menjadi sesat, Rachael! Manusia menciptakan

Tuhan yang menciptakan manusia! How amusing is that!

Dari kutipan di atas dapat dilihat selain Rick memiliki karakter keras kepala, dia juga memiliki karakter terbuka. Walaupun ada perbedaan antara Rick dan Rachel, tetapi dia tetap menghargai pendapat yang dilontarkan oleh lawan bicaranya.

\section{(2) Rachael}

Tokoh kedua yang ada dalam cerita "Kedai Kopi Odyssey" dalam cerpen "Partikel-partikel Tuhan" yaitu Rachael, kekasih Rick. Karakter yang dimiliki oleh Rachael hampir sama seperti Rick, mereka sama-sama memiliki kepribadian terbuka. Sama seperti Rick, Rachael juga menghargai apa yang dilontarkan oleh lawan bicaranya. Selain itu Rachel juga sosok pendengar yang baik, ia selalu merespons ucapan lawan bicaranya dengan positif tanpa menjatuhkan atau memojokkan.

“... Lagi pula, Rachael, terlepas dari siapa yang menciptakan siapa, dalam teisme selalu ada dua pihak yang merasa berkepentingan..."

"Jadi maksudmu hubungan antara manusia dan Tuhan adalah pertemuan dua kepentingan yang sama-sama bersifat egois? Begitu?"

"Persis, Rachael!..."

Pada kutipan tersebut dapat dilihat bahwa Rachael memiliki karakter yang terbuka, menghargai pendapat Rick mengenai konsepsi Tuhan dari sudut pandang manusia. Selain itu Rachael juga merespons ucapan Rick dengan tidak menyinggung perasaan Rick.

\section{c. Latar}

Menurut Abrams (dalam Nurgiyantoro, 2013) latar atau setting disebut juga sebagai landas tumpu, menunjukkan pada pengertian tempat, hubungan waktu sejarah, dan lingkungan sosial tempat terjadinya peristiwa-peristiwa yang diceritakan. Latar dalam cerita dituliskan untuk menciptakan suasana yang realistis dalam cerita. Latar juga menjadikan pembaca menjadi lebih dekat dengan cerita karena pembaca dapat merasakan, menilai kebenaran dari apa yang diceritakan. Oleh karenanya, latar menjadi pendukung yang kehadirannya sangat penting. Berikut ini latar yang terdapat pada cerita "Kedai Kopi Odyssey". 


\section{(1) Latar Tempat}

Latar tempat pertama yang ada dalam cerita ini, yaitu "Kota J". Sebenarnya tidak begitu jelas digambarkan. Namun, penulis memberikan simbolik yang menunjukkan terjadinya peristiwa tersebut di kota J. Cermati kutipan berikut.

Di meja nomor 11 yang bersisian dengan jendela yang menghadap ke kota $\mathrm{J}$, sepasang kekasih, lelaki dan perempuan, sedang seru membicarakan sesuatu.

Dari kutipan di atas dapat dilihat bahwa penulis menggambarkan kalau terjadinya peristiwa tersebut di sebuah kedai kopi tepatnya di kota J.

Latar tempat yang kedua dalam cerita "Kedai Kopi Odyssey" adalah kedai kopi. Di tempat inilah Rick dan Rachel bertemu dan berbincang- bincang mengenai suatu hal. Ditemani dengan Potongan musik Also Sprach Zarathustra dari Richard Strauss. Perhatikan kutipan berikut.

Suasana kelam dipekatkan oleh cuaca yang mendung. Hanya sedikit lampu yang menerangi kedai itu.

Potongan musik Also Sprach Zarathustra dari Richard Strauss yang mendadak muncul membuat suasana kedai itu sejenak menjadi agak mencekam.

Dari kutipan tersebut membuktikan bahwa latar yang membangun cerita ini adalah sebuah kedai kopi.

\section{(2) Latar Waktu}

Dalam cerita "Kedai Kopi Odyssey" latar waktu yang dimunculkan yaitu sore hari. Tepat dimana Rick dan Rachael sedang berada di sebuah kedai kopi. Dapat dilihat pada kutipan berikut.

Suasana kelam dipekatkan oleh cuaca yang mendung. Hanya sedikit lampu yang menerangi kedai itu.

Kutipan di atas dapat membuktikan bahwa latar waktu yang dimunculkan yaitu sore hari. Digambarkan bahwa hanya sedikit lampu yang menyala, hal ini karena waktu yang masih sore dan ketika menjelang malam hari baru lampulampu dinyalakan.

\section{d. Sudut Pandang}

Sudut pandang adalah sarana dalam cerita yang dilakukan oleh pengarang untuk menempatkan tokoh-tokoh dalam cerita yang dituliskannya. Penentuan sudut pandang ini merupakan strategi penulis untuk mengungkapkan gagasannya dalam cerita melewati tokoh-tokoh yang di kisahkannya. Sudut pandang dalam cerita secara garis besar itu dibedakan menjadi persona pertama "aku" dan persona ketiga "dia". 
Pada cerita "Kedai Kopi Odyssey" ini menggunakan sudut pandang persona ketiga. Nurgiyantoro (2013) mengungkapkan bahwa dalam sudut pandang ini, cerita dikisahkan dari sudut "dia", namun pengarang atau narator dapat menceritakan apa saja hal-hal yang menyangkut tokoh "dia" tersebut. Jadi pesona ketiga ini memosisikan narator sebagai yang mahatahu sehingga bisa bebas bergerak menceritakan apa saja. Cermatilah kutipan berikut.

Sebentar kemudian Rick mulai terkekeh. Serempak, keduanya tertawa terbahak-bahak hingga air mata mereka mengucur. Rachael menggeleng-gelengkan kepalanya dan mengetuk-ngetuk meja kaca di depannya.

Rachael menyelesaikan sisa tawanya. la menyeka air mata yang tinggal setetes di pelupuk mata kanannya.

Rachael dan Rick menatap beku ke tempat yang sama...

Kutipan tersebut membuktikan bahwa sudut pandang tokoh menggunakan sudut pandang persona ketiga "dia atau ia" atau penyebutan nama "Rick dan Rachael". Pada cerpen ini, banyak disebutkan nama tokoh, hal itu dituliskan supaya bisa mempermudah pembaca mengenali tokoh.

\section{e. Amanat}

Amanat adalah pesan moral yang ingin disampaikan oleh pengarang kepada pembacanya. Amanat merupakan sebuah makna yang terkandung di dalam sebuah cerita. Dalam setiap karya sastra pasti memiliki amanat yang akan pengarang sampaikan. Dalam cerpen ini terdapat pesan atau amanat yang disampaikan secara tersirat maupun yang tersurat. Amanat atau pesan moral dalam cerpen ini di antaranya, (1) kita harus terbuka dan memiliki wawasan yang luas, dan (2) tidak menghakimi jika terjadi perbedaan pendapat. Perhatikan kutipan berikut.

"Lantas, jika memang Tuhan...atau apa pun itu yang bisa disebut sebagai entitas superior...memiliki kepentingan, apakah itu salah?"

"Barangkali tidak. Tetapi, Tuhan yang memiliki kepentingan adalah Tuhan yang 'dimanusiakan'... dan itu sungguh banal, seperti khayalan orang-orang zaman dulu.

"Jadi maksudmu hubungan antara manusia dan Tuhan adalah pertemuan dua kepentingan yang sama-sama bersifat egois? Begitu?"

Pada kutipan tersebut dapat dilihat bahwa antara Rick dan Rachael memiliki wawasan yang luas mengenai Tuhan. Walaupun demikian mereka berdua tetap terbuka dan mau menerima perbedaan pendapat tanpa menghakimi satu sama lain.

\section{f. Tema}

Tema adalah pokok pikiran atau dasar cerita yang dipakai pengarang dalam menuliskan suatu karya. Tema cerita berbeda dengan judul cerita. Pada cerita "Kedai Kopi Odyssey" memiliki dua tema, antara lain secara luas dan secara sempit. Secara luas cerita ini memiliki tema ketuhanan, sedangkan secara sempit 
memiliki tema kebersamaan dalam perbedaan. Dapat dilihat pada kutipan berikut.

"Barangkali tidak. Tetapi, Tuhan yang memiliki kepentingan adalah Tuhan yang 'dimanusiakan'... dan itu sungguh banal, seperti khayalan orang-orang zaman dulu.

"Dan itulah yang membuat orang-orang menjadi sesat, Rachael! Manusia menciptakan Tuhan yang menciptakan manusia!

Kutipan di atas dapat membuktikan bahwa tema pada cerita "Kedai Kopi Odyssey" yaitu ketuhanan. Dalam hal ini, Rick dan Rachael membicarakan tentang konsepsi Tuhan dari sudut pandang manusia.

\footnotetext{
"Jadi maksudmu hubungan antara manusia dan Tuhan adalah pertemuan dua kepentingan yang sama-sama bersifat egois? Begitu?"

"Persis, Rachael! Menurutku, jika kamu mau mempercayai Tuhan, kamu harus mencoba untuk menjadikan hubunganmu dengan-Nya lepas dari segala kepentingan."

"Yakni dengan cara apa?"

"Dengan menjadi ateis sepertiku, Sayang!" "Itu artinya tidak ada jalan keluar!"
}

Dari kutipan tersebut dapat dilihat bahwa Rick dan Rachael tetap bersama dan saling menghargai pendapat atau keputusan masing-masing. Mereka berdua memiliki sikap toleransi yang sangat tinggi dalam menjalin hubungan.

\section{Analisis Unsur Ekstrinsik}

\section{a. Nilai-Nilai dalam Cerita}

Manusia dalam lingkungan masyarakatnya pasti tidak lepas dari nilai-nilai. Sistem nilai ini bisa menjadi pegangan atau memberikan makna kepada kehidupan masyarakat tersebut. Berdasarkan hasil kajian yang sudah dilakukan, ditemukan nilai pada cerita "Kedai Kopi Odyssey", sebagai berikut.

Cerita yang ditulis oleh Leopold A. Surya Indrawan dengan judul "Kedai Kopi Odyssey" tergambar nilai-nilai sosial yang berkembang di lingkungan masyarakatnya. Menurut Koentjaraningrat masyarakat adalah kesatuan hidup manusia yang saling berinteraksi menurut suatu sistem adat tertentu yang bersifat kontinu dan terikat oleh suatu rasa identitas yang sama. Oleh karenanya, nilai sosial dalam masyarakat ini memiliki peranan penting dalam masyarakat sebagai makhluk sosial yang terhubung melalui berbagai interaksi antar sesama manusia. Berikut ini nilai sosial yang digambarkan pengarang cerita "Kedai Kopi Odyssey".

Toleransi adalah sikap saling menghargai dan menghormati terhadap suatu perbedaan baik antar kelompok ataupun antar individu. Dalam cerita "Kedai Kopi Odyssey" mengandung toleransi yang tinggi antar tokoh. Dalam hal ini adanya perbedaan yang terjadi antara Rick dan Rachael, baik perbedaan pendapat ataupun perbedaan keyakinan yang mereka anut. Tetapi, mereka tetap menghargai satu sama lain dan tidak menyudutkan salah satunya dapat dilihat pada kutipan berikut. 
"Jadi maksudmu hubungan antara manusia dan Tuhan adalah pertemuan dua kepentingan yang sama-sama bersifat egois? Begitu?"

"Persis, Rachael! Menurutku, jika kamu mau mempercayai Tuhan, kamu harus mencoba untuk menjadikan hubunganmu dengan-Nya lepas dari segala kepentingan."

"Yakni dengan cara apa?"

"Dengan menjadi ateis sepertiku, Sayang!" "Itu artinya tidak ada jalan keluar!"

\section{b. Realitas Sosial Objektif}

Realitas sosial objektif yang ditemukan dalam cerita "Kedai Kopi Odyssey" yang ditulis dalam cerpen "Partikel-partikel Tuhan" sebagai berikut.

\section{(1) Agama}

Realitas sosial objektif agama yang ditemukan dalam cerpen ini adalah berbagai penganut agama yang bisa berkumpul membahas agama untuk kepentingan persatuan dan bertukar gagasan bukan untuk memperdebatkan ajaran mana yang paling benar.

"Jadi, kamu percaya bahwa ada sesosok organisme omnipoten, yang mampu menciptakan langit dan bumi, dan mampu mengendalikan alam semesta?"

"Tidak sepenuhnya, Rick. Entah bisa disebut organisme atau bukan. Aku hanya bilang bahwa aku percaya ada entitas superior yang menciptakan dan mengendalikan kita. Lagi pula, kenapa hanya manusia yang bisa membangun peradaban di antara spesies-spesies yang lain?"

Berdasarkan kutipan di atas diketahui bahwa manusia yang menganut agama berbeda dapat berkumpul dalam satu ruangan membahas mengenai banyak hal bahkan tentang agama. Peristiwa tersebut dekat dengan realitas saat ini di mana tidak ada larangan bagi manusia untuk berbaur secara sosial bersama manusia yang memiliki ajaran yang berbeda.

\section{(2) Kebersamaan}

Realitas objektif kebersamaan dalam cerpen ini adalah tradisi silaturahmi. Status hubungan yang dimiliki manusia dengan manusia lain mendorong terjadinya silaturahmi, yakni seperti keluarga, sahabat, pasangan kekasih, dan sebagainya. Pada cerpen ini bentuk kebersamaan ditunjukkan dengan bertemunya sepasang kekasih.

Di meja nomor 11 yang bersisian dengan jendela yang menghadap ke kota J, sepasang kekasih, lelaki dan perempuan, sedang seru membicarakan sesuatu.

\section{c. Realitas Sosial Subjektif}

Realitas sosial subjektif yang ditemukan dalam cerita "Kedai Kopi Odyssey" yang ditulis dalam cerpen "Partikel-partikel Tuhan" sebagai berikut. 


\title{
(1) Agama
}

Realitas sosial subjektif agama yang ditemukan dalam cerpen ini adalah adanya perbedaan agama dalam masyarakat. Pada cerita "Kedai Kopi Odyssey" ditunjukkan dengan seorang yang beragama Kristen dan ada pula yang tidak beragama, ateis. Pilihan agama tersebut merupakan hak bagi setiap manusia. Setiap manusia memiliki wewenang untuk menentukan kepercayaannya sesuai dengan keyakinan masing-masing.

\footnotetext{
"Persis, Rachael! Menurutku, jika kamu mau mempercayai Tuhan, kamu harus mencoba untuk menjadikan hubunganmu dengan-Nya lepas dari segala kepentingan."

"Yakni dengan cara apa?"

"Dengan menjadi ateis sepertiku, Sayang!"

"Itu artinya tidak ada jalan keluar!"
}

\section{(2) Kebersamaan}

Realitas sosial subjektif kebersamaan dalam cerita "Kedai Kopi Odyssey" adalah membangun kebersamaan di kedai kopi. Sepasang kekasih dalam kisah ini bertemu dan duduk bersama di sebuah kedai kopi yang kala itu diselimuti cuaca yang sejuk karena mendung. Mereka menganggap bahwa kedai kopi menjadi tempat nyaman untuk berkumpul, bersilaturahmi, dan menciptakan kebersamaan.

\begin{abstract}
Suasana kelam dipekatkan oleh cuaca yang mendung. Hanya sedikit lampu yang menerangi kedai itu. Tiap mejanya disekat dengan balok kaca hitam yang menjulang. Di salah satu dindingnya terdapat barisan huruf sans serif bercahaya putih yang membentuk kalimat: "The very meaningless of life forces man to create his own meaning." (Stanley Kubrick). Potongan musik Also Sprach Zarathustra dari Richard Strauss yang mendadak muncul membuat suasana kedai itu sejenak menjadi agak mencekam. Suara musik itu berasal dari film 2001: A Space Odyssey yang baru saja disetel di keempat televisi 32 inci yang tergantung di langitlangit.

Di meja nomor 11 yang bersisian dengan jendela yang menghadap ke kota $\mathrm{J}$, sepasang kekasih, lelaki dan perempuan, sedang seru membicarakan sesuatu.
\end{abstract}

\section{Proses Alih Wahana}

Naskah drama "Kedai Kopi Odyssey" yang merupakan bentuk alih wahana dari salah satu cerpen dari kumpulan cerpen "Partikel-partikel Tuhan". Sebagaimana judul cerpen, yakni "Kedai Kopi Odyssey", peneliti tetap mempertahankan judul asli untuk naskah drama. Namun, dalam proses alih wahana ini tentu saja terdapat perubahan baik penambahan atau pengurangan. Berikut perubahan yang peneliti lakukan antara lain.

\section{a. Tokoh}

Tokoh merupakan penggerak alur cerita. Dalam cerita yang dialihwahanakan hanya terdapat dua tokoh yang salah satunya adalah ateis. Sedangkan pada alih wahana ini peneliti menambahkan satu tokoh tambahan bernama Aloysia yang 
beragama muslim. Jadi terdapat satu orang dengan keyakinan ateis, satu orang muslim, dan satu orang berkeyakinan Kristen, dalam naskah alih wahana ada tiga tokoh.

Semula hubungan tokoh merupakan sepasang kekasih, namun karena menambahkan tokoh cerita maka status hubungan antar tokoh adalah sahabat. Perubahan ini dilakukan dengan harapan supaya lebih dekat dengan kehidupan saat ini. Sahabat dan pasangan merupakan hubungan yang sama eratnya. Penambahan tokoh ini juga dilakukan guna menciptakan dialog yang lebih interaktif lagi. Perhatikan perubahan berikut.

\section{Pada cerita:}

Di meja nomor 11 yang bersisian dengan jendela yang menghadap ke kota $\mathrm{J}$, sepasang kekasih, lelaki dan perempuan, sedang seru membicarakan sesuatu.

\section{Pada Naskah Drama:}

Hari ini, siang tampak lebih gelap tidak seperti yang seharusnya. Muramnya suasana siang itu tidak menyurutkan rencana pertemuan 3 sekawan, yakni Rick, Rachel, dan Aloysia.

\section{b. Dialog}

Dalam melakukan alih wahana ini peneliti mengubah dialog dengan melakukan penambahan dialog sebagai bentuk interaksi tiga tokoh. Pada cerpen dialog dimulai dengan langsung membahas inti pembahasan sedangkan dalam naskah drama ini ditambahkan obrolan-obrolan ringan yang nantinya terhubung ke pembahasan inti. Selain itu, karena adanya penambahan tokoh, maka terdapat pula dialog-dialog baru yang dimunculkan. Namun, kehadiran dialog ini tidak mengubah inti cerita melainkan untuk menghantarkan kepada pembahasan topik yang serius sekaligus supaya lebih menarik. Berikut sedikit kutipan yang memperjelas proses perubahan dalam dialog.

\section{Pada cerita:}

"Jadi, kamu percaya bahwa ada sesosok organisme omnipoten, yang mampu menciptakan langit dan bumi, dan mampu mengendalikan alam semesta?"

"Tidak sepenuhnya, Rick. Entah bisa disebut organisme atau bukan. Aku hanya bilang bahwa aku percaya ada entitas superior yang menciptakan dan mengendalikan kita. Lagi pula, kenapa hanya manusia yang bisa membangun peradaban di antara spesies-spesies yang lain?"

\section{Pada Naskah Drama:}

Rick Aloysia : "Hai, Rachel!" (Mereka berteriak dengan lantang)

Suara kencang kedua sahabatnya membuat Rachel terkejut. Sebelum menutup buku yang sedang dibacanya dengan sedikit keras, sungguh Rachel tidak tahan menyembunyikan lebih lama senyum kecil di bibirnya.

Rachel : "Sudah lama tidak bertemu! Kebiasaan kalian yang sering mengejutkanku ternyata masih saja sama, huh!" (Sembari menepuk pundak Rick)

\section{c. Menambahkan Narasi untuk Narator}

Dalam naskah drama ini di konstruksi bagian untuk narator. Narasi untuk narator ini ada yang mempertahankan narasi dari cerita asli dan ada pula yang 
ditambahkan kalimatnya ataupun mengganti konstruksi kalimatnya. Narasi bagi narator ada yang di awal, akhir, dan di tengah-tengah dialog. Berikut ini salah satu bentuk perubahan berupa penambahan dan pengurangan dalam segi narasi.

\section{Pada cerita:}

Di meja nomor 11 yang bersisian dengan jendela yang menghadap ke kota $\mathrm{J}$, sepasang kekasih, lelaki dan perempuan, sedang seru membicarakan sesuatu.

"Jadi, kamu percaya bahwa ada sesosok organisme omnipoten, yang mampu menciptakan langit dan bumi, dan mampu mengendalikan alam semesta?"

\section{Pada naskah drama:}

Pesanan Rich dan Aloysia tiba.

Ada jeda di antara mereka. Semua asyik mencicipi hidangan yang baru saja tiba. Terlihat Rick tampak gusar. Seperti ada yang ingin dia sampaikan dan tampaknya akan berujung serius.

Rick : "Hmm.... Aku tidak percaya akan adanya suatu organisme atau siapa pun itu yang menciptakan langit, bumi beserta isinya. Kalian masih percaya akan Tuhan yang mengendalikan semua yang ada di semesta ini?"

\section{d. Menyederhanakan Kalimat}

Sejatinya sederhana di sini bukan mengubah kalimat menjadi pendek. Namun, mengonstruksi supaya makna yang ingin disampaikan dalam setiap dialog maupun narasi menjadi sederhana atau mudah dimengerti. Dalam proses ini peneliti mengubah konstruksi kalimat, membuat kalimat menjadi tidak panjang dengan memberikan pungtuasi, dan sebagainya. Berikut contoh menyederhanakan kalimat.

\section{Pada cerita:}

"Tidak sepenuhnya, Rick. Entah bisa disebut organisme atau bukan. Aku hanya bilang bahwa aku percaya ada entitas superior yang menciptakan dan mengendalikan kita. Lagi pula, kenapa hanya manusia yang bisa membangun peradaban di antara spesies-spesies yang lain?"

"Kebetulan, Rachel! Itu semua terjadi karena rangkaian kebetulan!"

\section{Pada naskah drama:}

Aloysia : "Ya, tentu saja. Tuhan adalah entitas superior yang menciptakan kita dan mengatur segala sesuatu yang baik bagi makhluknya. Kalau kau tidak mengakui Tuhan yang mengendalikan semesta ini, lalu bagaimana manusia diciptakan?"

Rick : "Kebetulan, Aloysia! Semua yang terjadi di dunia ini hanya kebetulan! Kau tahu? Semacam sesuatu yang memang harus terjadi tanpa peduli alasannya."

\section{e. Mengubah Diksi}

Cerita ini termasuk cerita yang pembahasannya cukup sulit. Terdapat diksidiksi yang jarang digunakan. Untuk mengatasi hal tersebut dan supaya menjadi mudah dimengerti, peneliti mengganti diksi tersebut dengan pada padanan kata atau arti dari diksi tersebut. Dalam hal ini peneliti menggunakan Kamus Besar Bahasa Indonesia (KBBI) secara daring dan seluncur internet untuk memahami diksi yang peneliti tidak ketahui tersebut. Karena tidak ada padanan katanya 
peneliti pun memilih untuk menggantinya dengan memperjelas kata melalui arti sebenarnya dari kata tersebut. Berikut contoh mengubah diksi.

\section{Pada cerita:}

"Dan itulah yang membuat orang-orang menjadi sesat, Rachael! Manusia menciptakan Tuhan yang menciptakan manusia! How amusing is that! Lagi pula,

Rachael, terlepas dari siapa yang menciptakan siapa, dalam teisme selalu ada dua pihak yang merasa berkepentingan. Yang pertama merasa berkepentingan untuk mengatur segala sesuatu tanpa alasan yang jelas...orang- orang beriman dengan naif menyebut tindakan itu didasari oleh cinta agape....dan yang kedua merasa berkepentingan untuk senantiasa menyembah Sang Pengatur itu supaya la tidak murka dan mengabulkan doadoa mereka."

\section{Pada naskah drama:}

Aloysia menyimak dengan tenang

Rick : "Dan itulah yang membuat orang-orang menjadi sesat Aloysia! Manusia menciptakan Tuhan yang menciptakan manusia?! Begini, jika memang Tuhan menciptakan manusia, manusia jugalah yang menciptakan Tuhan dengan selalu menyembah-Nya. Maksudku, la tidak akan menjadi Tuhan jika tidak ada yang menyembah dan tunduk kepada-Nya. Lagi pula Aloysia, terlepas dari siapa yang menciptakan siapa, dalam teisme selalu ada dua pihak yang merasa berkepentingan. Yang pertama merasa berkepentingan untuk mengatur segala sesuatu tanpa alasan yang jelas, seperti orang-orang beriman dengan naif menyebut tindakan itu didasari oleh cinta dalam bentuk mengadakan perjamuan persaudaraan setelah ibadah dengan mengundang umat yang kurang mampu. Dan yang kedua merasa berkepentingan untuk senantiasa menyembah Sang Pengatur itu supaya la tidak murka dan mengabulkan doa-doa mereka."

\section{Penutup}

Cerita "Kedai Kopi Odyssey" dalam kumpulan tulisan cerpen "Partikelpartikel Tuhan" karya Leopold Adi Surya Indrawan memiliki isi cerita yang dekat dengan kehidupan masyarakat yaitu sosial dan agama. Unsur intrinsik pada cerita "Kedai Kopi Odyssey" berisikan unsur alur maju, terdapat dua tokoh Ricky dan Rachel, latar tempat di sebuah kedai kopi di kota J dan latar waktu sore hari, sudut pandang persona ketiga, amanat berisikan nilai moral dan toleransi, dan unsur terakhir tema yang berisikan tentang ketuhanan. Unsur intrinsik membentuk cerita yang sederhana berisikan dialog mengenai ketuhanan dan kemanusiaan yang berlatar kedai kopi. Kemudian terdapat pula unsur ekstrinsik yang erat hubungannya dengan kehidupan masyarakat yaitu mencangkup latar belakang penulis, nilai-nilai yang terkandung pada cerita, realitas sosial objektif dan realitas sosial subjektif.

Adapun aspek sosial dapat dilihat dari latar dan kegiatan tokoh dalam cerita tersebut, sedangkan aspek agama dapat dilihat dari dialog antar tokoh yang masing-masing dari mereka memiliki keyakinan berbeda. Selain itu dalam pengkajian cerita "Kedai Kopi Odyssey" penyusun memilih menggunakan pendekatan sosiologi sastra karena cerpen tersebut mencerminkan kehidupan sosial masyarakat.

Berdasarkan garis besar dalam cerita "Kedai Kopi Odyssey" ialah tentang pasangan yang memiliki keyakinan berbeda yang kemudian dialihwahanakan 
dan diubah tokohnya menjadi tiga orang sahabat yang memiliki keyakinan yang berbeda. Terdapat tahap-tahap proses alih wahana yaitu, perubahan tokoh, dialog, menambahkan narasi untuk narator, menyederhanakan kalimat dan mengubah diksi.

\section{Daftar Pustaka}

Aminuddin. (2015). Pengantar Apresiasi Karya Sastra. Bandung: Angkasa.

Damono, S. D. (2012). Alih Wahana. Jakarta: Editum.

Endraswara, S. (2013). Metodologi Penelitian Sastra. Yogyakarta: CAPS.

Fakhrurozi, J., \& Adrian, Q. J. (2021). Kajian dan Praktik Ekranisasi Cerpen

Perempuan di Rumah Panggung ke Film Pendek Angkon. Deiksis: Jurnal Pendidikan Bahasa dan Sastra Indonesia, 8(1), 31. https://doi.org/10.33603/dj.v8i1.4417

Hidayaturrahman, M. (2020). Teori Sosial Empirik Untuk Penelitian IImiah (Skripsi, Tesis dan Disertasi). Malang: Edulitera.

Indrawan, L. A. S. (2014). Partikel-partikel Tuhan. In Kumpulan Cerpen Koran Tempo Minggu 2014: Partikel-partikel Tuhan dan Cerita Lainnya (hal. 919). Diambil dari https://www.scribd.com/document/385437235/e-bookkumpulan-cerpen-koran-tempo-minggu-2014-pdf

Lesmana, I. B. G. A. S., Udasmoro, W., \& Hayuningsih, A. A. C. (2021). Konstruksi dan Kontestasi Kuasa Perempuan pada Naskah Drama Les Bonnes Karya Jean Genet. Diglosia: Jurnal Kajian Bahasa, Sastra, dan Pengajarannya, 4(1), 65-78. https://doi.org/10.30872/diglosia.v4i1.124

Mahsa, M. (2021). Representasi Masyarakat Bali dalam Novel Tarian Bumi Karya Oka Rusmini (Tinjauan Sosiologi Sastra). Kande, 2(2), 219-230.

Moleong, L. J. (2016). Metode Penelitian Kualitatif. Bandung: Remaja Rosdakarya.

Nurgiyantoro, B. (2013). Teori Pengkajian Fiksi. Yogyakarta: Gadjah Mada University Press.

Nurhasanah, E. (2019). Kajian Alih Wahana Cerita Pendek "Dewi Amor" Karya Eka Kurniawan Ke Dalam Naskah Drama Pendekatan Psikologi Sastra. Prosiding Seminar Internasional Riksa Bahasa VIII, 1731-1738. Diambil dari http://proceedings.upi.edu/index.php/riksabahasa/article/view/1048

Rahmah, Y., \& Meinati, D. (2021). RAMPO NOIR: Proses Alih Wahana Cerpen "Kagami Jikoku" Karya Edogawa Rampo. Kiryoku, 5(1), 54-62. https://doi.org/10.14710/kiryoku.v5i1.54-62

Ratna, N. K. (2013). Teori, Metode, dan Teknik Penelitian Sastra. Yogyakarta: Pustaka Pelajar.

Ritzer, G. (2014). Teori Sosiologi dari Sosiologi Klasik sampai Perkembangan Terakhir Postmodern. Yogyakarta: Pustaka Pelajar.

Rosdiani, S., Nurhasanah, E., \& Triyadi, S. (2021). Realitas Sosial dalam Novel Perempuan yang Menangis Kepada Bulan Hitam Karya Dian Purnomo. Metamorfosa, 9(2), 82-100. Diambil dari https://ejournal.bbg.ac.id/metamorfosa/article/view/1483

Sehandi, Y. (2014). Mengenal 25 Teori Sastra. Yogyakarta: Ombak. 
Sugiyono. (2016). Metodologi Penelitian Kuantitatif, Kualitatif, dan R\&D. Bandung: Alfabeta.

Tyas, T. (2018). Analisis Sosiologi Karya Sastra terhadap Novel Suti Karangan Sapardi Djoko Damono. Yogyakarta: Universitas Sanata Dharma. Diambil dari https://repository.usd.ac.id/31029/2/131224023_full.pdf 